\title{
Genistein inhibits PDGF-stimulated proteoglycan synthesis in vascular smooth muscle without blocking PDGFß receptor phosphorylation
}

Little AM, Peter; Getachew, Robel; Rezaei, Hossein; Sanchez-Guerrero, Estella; Khachigian, L.M.; Wang, Haitao; LIAO, SUFEN

https://researchrepository.rmit.edu.au/esploro/outputs/9921858252201341/filesAndLinks?institution=61RMIT_INST\&index=null

Little AM, P., Getachew, R., Rezaei, H., Sanchez-Guerrero, E., Khachigian, L. M., Wang, H., LIAO, S., Zheng, W., Ballinger, M., \& Osman, N. (2012). Genistein inhibits PDGF-stimulated proteoglycan synthesis in vascular smooth muscle without blocking PDGFß receptor phosphorylation. Archives of Biochemistry and Biophysics, 525(1), 25-31. https://doi.org/10.1016/j.abb.2012.05.025

Document Version: Accepted Manuscript

Published Version: https://doi.org/10.1016/j.abb.2012.05.025 
Thank you for downloading this document from the RMIT Research Repository.

The RMIT Research Repository is an open access database showcasing the research outputs of RMIT University researchers.

RMIT Research Repository: http://researchbank.rmit.edu.au/

\section{Citation:}

Little AM, P, Getachew, R, Rezaei, H, Sanchez-Guerrero, E, Khachigian, L, Wang, H, LIAO, S, Zheng, W, Ballinger, M and Osman, N 2012, 'Genistein inhibits PDGF-stimulated proteoglycan synthesis in vascular smooth muscle without blocking PDGFß receptor phosphorylation', Archives of Biochemistry and Biophysics, vol. 525, no. 1, pp. 25-31.

See this record in the RMIT Research Repository at:

http://researchbank.rmit.edu.au/view/rmit:16833

Version: Accepted Manuscript

Copyright Statement: ㄷ 2012 Elsevier Inc. All rights reserved.

Link to Published Version:

http://dx.doi.org/10.1016/j.abb.2012.05.025 


\section{Accepted Manuscript}

Genistein inhibits PDGF-stimulated proteoglycan synthesis in vascular smooth muscle without blocking PDGF $\beta$ receptor phosphorylation

Peter. J. Little, Robel Getachew, Hossein Babaahmadi Rezaei, Sanchez-

Guerrero Estella, Levon. M. Khachigian, Haitao Wang, Sufen Liao, Wenhua Zheng, Mandy L. Ballinger, Narin Osman

PII:

S0003-9861(12)00236-6

DOI: http://dx.doi.org/10.1016/j.abb.2012.05.025

Reference: $\quad$ YABBI 6260

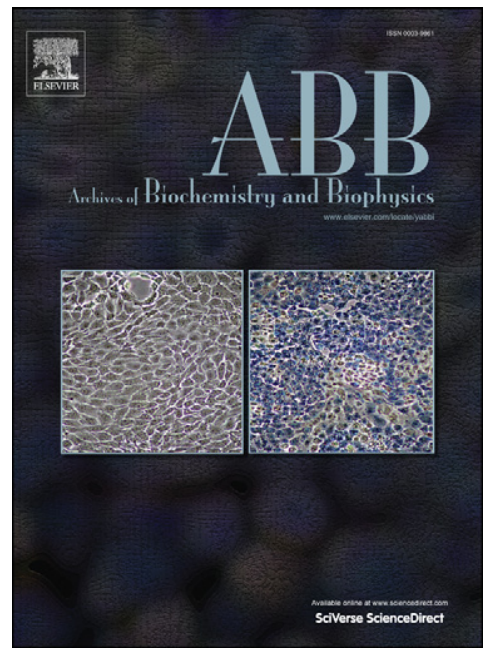

To appear in: $\quad$ Archives of Biochemistry and Biophysics

Received Date: $\quad 2$ March 2012

Revised Date: $\quad 28$ May 2012

Please cite this article as: r.J. Little, R. Getachew, H.B. Rezaei, S-G. Estella, n.M. Khachigian, H. Wang, S. Liao, W. Zheng, M.L. Ballinger, N. Osman, Genistein inhibits PDGF-stimulated proteoglycan synthesis in vascular smooth muscle without blocking PDGF $\beta$ receptor phosphorylation, Archives of Biochemistry and Biophysics (2012), doi: http://dx.doi.org/10.1016/j.abb.2012.05.025

This is a PDF file of an unedited manuscript that has been accepted for publication. As a service to our customers we are providing this early version of the manuscript. The manuscript will undergo copyediting, typesetting, and review of the resulting proof before it is published in its final form. Please note that during the production process errors may be discovered which could affect the content, and all legal disclaimers that apply to the journal pertain. 


\section{Genistein inhibits PDGF-stimulated}

\section{proteoglycan synthesis in vascular smooth muscle}

\section{without blocking PDGF $\beta$ receptor phosphorylation}

${ }^{1,2}$ Little, Peter. J. ${ }^{1}$ Getachew, Robel, ${ }^{1,3}$ Hossein Babaahmadi Rezaei ${ }^{4}$ Sanchez-

Guerrero,Estella, ${ }^{4}$ Khachigian, Levon. M., ${ }^{5}$ Wang, Haitao, ${ }^{5}$ Liao, Sufen, ${ }^{5}$ Zheng, Wenhua,

${ }^{2 \#}$ Ballinger, Mandy L. and ${ }^{1,2}$ Osman, Narin

${ }^{1}$ Discipline of Pharmacy, School of Medical Sciences and Diabetes Complications Group, Health Innovations Research Institute, RMIT University, Bundoora, VIC 3083 Australia ${ }^{2}$ Monash University, Departments of Medicine and Immunology, Central and Eastern Clinical School, Alfred Health, Melbourne, Victoria, Australia, ${ }^{3}$ Department of Clinical Biochemistry, Tehran University Of Medical Sciences, Tehran, Iran, ${ }^{4}$ Centre for Vascular Research, UNSW Faculty of Medicine, Sydney, NSW 2052 Australia and ${ }^{5}$ Neuropharmcology, School of Pharmaceutical Sciences, Sun Yat-Sen University, 74 Zhongshan Road II, Guangzhou Guangdong 510080 China.

\# Present address: . \#Present address: Peter MacCallum Cancer Centre, St Andrews Place, East Melbourne, Victoria 3002, Australia

Running title: PDGF receptor phosphorylation and proteoglycan synthesis

Keywords: Genistein, proteoglycans, glycosaminoglycans, PDGF receptor phosphorylation, vascular smooth muscle

\section{Address correspondence to:}

Prof. Peter J. Little,

Discipline of Pharmacy, School of Medical Sciences and

Health Innovations Research Institute,

RMIT University,

Bundoora, Victoria 3083

Australia

Tel:

Email:

+61417530981

peter.little@rmit.edu.au 


\section{Abstract}

The signaling pathways that regulate the synthesis and structure of proteoglycans secreted by vascular smooth muscle cells are potential therapeutic targets for preventing lipid deposition in the early stage of atherosclerosis. PDGF stimulates both core protein expression and elongation of glycosaminoglycan (GAG) chains on proteoglycans. In this study we investigated the effects of the tyrosine kinase inhibitor genistein on PDGF mediated receptor phosphorylation and proteoglycan synthesis in human vascular smooth muscle cells. We demonstrate that genistein does not block phosphorylation of the activation site of the PDGF receptor at $\mathrm{Tyr}^{857}$ and two other downstream sites $\mathrm{Tyr}^{751}$ and $\mathrm{Tyr}^{1021}$. Genistein blocked PDGF-mediated proteoglycan core protein synthesis however it had no effect on GAG chain elongation. These results differ markedly to two other tyrosine kinase inhibitors, imatinib and Ki11502, that block PDGF receptor phosphorylation and PDGF mediated GAG elongation. We conclude that the action of genistein on core protein synthesis does not involve the PDGF receptor and that PDGF mediates GAG elongation via the PDGF receptor. 


\section{Introduction}

The underlying pathology of most cardiovascular disease (CVD) is atherosclerosis $[1,2]$. Atherosclerosis is characterized by a preinflammatory stage involving the deposition and retention of atherogenic lipoproteins by modified proteoglycans in the vessel wall followed by the later chronic non-resolving inflammatory stage involving the accumulation of immunogenic products and the formation of atherosclerotic plaques [35]. A recent human pathology study showed unequivocally that the deposition of extracellular low density lipoproteins (LDL) in association with the proteoglycan biglycan, precedes the inflammatory response [6, 7]. LDL binds to proteoglycans and specifically the chondroitin sulfate/dermatan sulfate (CS/DS) glycosaminoglycan (GAG) chains in an interaction known as the "response to retention" hypothesis which has recently been reviewed by Boren and colleagues $[3,8]$. Vasoactive and proatherogenic growth factors and hormones stimulate vascular smooth muscle cells (VSMC) resulting in an increase in the size of the GAG chains on secreted proteoglycans [9-12]. Longer GAG chains are associated with increased binding in vitro to LDL [9, 13, 14].

Genistein is a pharmacological and nutraceutical of broad interest because it is present in the diet at potentially efficacious levels [15]. First reports of the tyrosine kinase inhibitory activity of genistein came in 1987 when Akiyama found that tyrosine phosphorylation of the epidermal growth factor (EGF) receptor was decreased in the presence of genistein [16]. Recognised as a broad spectrum tyrosine kinase inhibitor, genistein exerts an inhibitory action by competitively inhibiting the binding of ATP in the kinase reaction [17]. The mechanism of action of genistein is probably the basis for its wide range of tyrosine kinase inhibition as the ATP binding domain is highly conserved 
[17]. As well as inhibition of the EGF receptor, genistein has also been reported as inhibiting the PDGF receptor (PDGFR) [18] and the Insulin-like Growth Factor (IGF) receptor [19].

Platelet-derived growth factor (PDGF) stimulates core protein expression for the CS/DS proteoglycan, versican, and also mediates elongation of GAG chains on all CS/DS proteoglycans secreted by VSMCs including, versican, biglycan and decorin $[10,20]$. Genistein is a broad spectrum ATP competitive tyrosine kinase inhibitor known to inhibit the effects of PDGF on VSMCs $[16,18,21,22]$. Genistein inhibits VSMC proliferation although it is almost two orders of magnitude less potent than compounds like imatinib and Ki11502 [21, 23].

An early finding in this area of signaling and proteoglycan synthesis was that PDGF-stimulated versican expression (in monkey VSMCs) was blocked by genistein, used as a tyrosine kinase inhibitor, but in the same experiments and therefore under identical conditions, the GAG elongation response to PDGF was not blocked by genistein [18]. This result lead to the interpretation that the signaling for core protein expression and GAG elongation were distinct processes and notably that the GAG elongation response mediated by PDGF was independent of the tyrosine kinase activity of the PDGF receptor [24].

We recently reported that two PDGF receptor inhibitors, Ki11502 [25] and imatinib [13] block PDGF receptor mediated core protein expression, in this case for biglycan, and also block GAG elongation in human VSMCs [13, 25]. This data strongly suggests that the GAG elongation effect of PDGF is mediated by PDGF receptor phosphorylation [26]. Thus, the question is unresolved as to why the protein tyrosine kinase inhibitor genistein 
which blocks PDGF stimulated proliferation and even blocks the PDGF expression of versican in VSMCs does not block PDGF stimulated GAG elongation [18]. This is a potentially very important pathway because imatinib treatment of human VSMCs leads to reduced binding of proteoglycans to LDL and reduced the deposition of lipid in the vessel wall of high fat fed $\mathrm{ApoE}^{-/-}$mice [13]. In view of the potential therapeutic implications for this area $[3,4,27,28]$ we have further investigated the signaling pathway through which PDGF mediates its effects on proteoglycan synthesis in human VSMCs and specifically investigated the role of the PDGF receptor and its autophosphorylation including an investigation of the effects of genistein on PDGF receptor phosphorylation and downstream signaling of proteoglycan synthesis.

We demonstrate that in intact VSMCs, genistein does not block PDGF receptor phosphorylation at $\mathrm{Tyr}^{857}$ which is the autophosphorylation and activation site nor does it block two other phosphorylation sites on the receptor. In contrast, two known PDGF receptor antagonists block PDGF receptor phosphorylation at all three target sites. PDGF stimulated versican expression is blocked by the three agents, and PDGF stimulated GAG elongation is blocked by the PDGF antagonists but not by genistein. These data demonstrate the specificity of the signaling pathways for proteoglycan core protein expression and GAG elongation providing an opportunity for the identification and development of specific antagonists of proteoglycan synthesis for potential use in diseases involving proteoglycans. 


\section{$2 \quad$ Materials and Methods.}

\subsection{Materials}

Genistein, daidzein, benzamidine hydrochloride, DEAE-Sephacel, Sepharose CL$6 \mathrm{~B}$, proteinase $\mathrm{K}$, chondroitin sulfate, $\mathrm{PDGF}$, thrombin and penicillin-streptomycin were from Sigma Chem Co. (St Louis, MO, USA). Imatinib was from Alfred Hospital Pharmacy. and PDGFR $\beta$ inhibitor Ki11502 from Calbiochem. Corp. Dulbecco's Modified Eagle Medium (DMEM) was from Invitrogen Corporation, USA. Foetal bovine serum (FBS) and penicillin-streptomycin-fungizone solution, PDGF BB, Sepharose CL-6B and other standard reagents were purchased from Sigma-Aldrich Australia. Sulfur-35 $\mathrm{Na}_{2} \mathrm{SO}_{4}\left(\left[{ }^{35} \mathrm{~S}\right]\right.$-sulfate $)$ and Trans ${ }^{35}$ STrans $\left[{ }^{35} \mathrm{~S}\right]-$ label $\left(\left[{ }^{35} \mathrm{~S}\right]-\mathrm{Met} / \mathrm{Cys}\right)$ were from MP Biomedicals, USA. Cetyl pyridinium chloride (CPC) was from Unilab Chemicals and Pharmaceuticals, Mumbai, India.

\subsection{Cell Culture}

Human VSMCs from internal mammary arteries and the saphenous veins were isolated and characterised as previously described [29] from patients undergoing coronary artery bypass grafting at Alfred Health (Melbourne, Australia.). The acquisition of the vessel segments was approved by the Alfred Hospital Human Ethics committee. HSMCs and WKY12-22 SMCs for Egr-1 experiments were cultured in Waymouth's medium (Life Technologies, Inc.), $\mathrm{pH}$ 7.4, supplemented with 10 units/ml penicillin, 10ug/ml streptomycin, and $10 \%$ fetal calf serum at $37^{\circ} \mathrm{C}$ and $5 \% \mathrm{CO}_{2}$ in an air jacketed $\mathrm{CO}_{2}$ incubator. SMCs were growth-arrested in serum-free medium for $24 \mathrm{~h}$ prior to inhibitors addition. HSMCs were incubated with genistein $100 \mu \mathrm{M}$, imatinib $1 \mu \mathrm{M}$, 
daidzein $100 \mu \mathrm{M}$, Ki11502 (300 nM) and PDGFR $\beta$ inhibitor $10 \mu \mathrm{M}$ for $1 \mathrm{~h}$. Cells were then stimulated with $50 \mathrm{ng} / \mathrm{ml}$ PDGF-BB for $30 \mathrm{~min}$ before mRNA and protein isolation.

\subsection{Quantitation of radiolabel incorporation into proteoglycans}

Quiescent human VSMCs in 24 well plates were treated in $0.5 \mathrm{ml} 5 \mathrm{mM}$ glucose DMEM, 0.1\% FBS, 0.1\% DMSO inhibitors as detailed in Results section and exposed to $\left[{ }^{35} \mathrm{~S}_{-}-\mathrm{SO}_{4}(50 \mu \mathrm{Ci} / \mathrm{ml})\right.$ in the presence of PDGF $(50 \mathrm{ng} / \mathrm{ml})$ for $24 \mathrm{~h}$. Secreted proteoglycans were harvested and $\left[{ }^{35} \mathrm{~S}\right]-\mathrm{SO}_{4}$ incorporation into proteoglycans was quantitated using the CPC precipitation assay [9, 30-32].

\subsection{SDS-PAGE determination of proteoglycan size}

Proteoglycans labelled with $\left[{ }^{35} \mathrm{~S}\right]$ sulfate or $\left[{ }^{35} \mathrm{~S}\right]-\mathrm{Met} / \mathrm{Cys}$ were prepared for SDSPAGE by isolation through DEAE sephacel anionic exchange mini columns. Samples were added to pre-equilibrated columns, then washed extensively with low salt buffer (8M Urea, 0.25M NaCl, 2 mM disodium EDTA, 0.5\% Triton X-100). Proteoglycans were eluted with high salt buffer (8M Urea, $3 \mathrm{M} \mathrm{NaCl}, 2 \mathrm{mM}$ disodium EDTA, $0.5 \%$ Triton X-100) Aliquots $(25,000 \mathrm{cpm})$ were precipitated $(1.3 \%$ potassium acetate, $95 \%$ ethanol) and chondroitin sulfate was added as a cold carrier. Samples were resuspended in buffer (8M Urea, 2mM disodium EDTA, $\mathrm{pH} 7.5$ ), to which an equal volume of sample buffer was added. Radiolabelled proteoglycans were separated on 4-13\% acrylamide gels with a $3 \%$ stacking gel at $50 \mathrm{~V}$ overnight. $\left[{ }^{14} \mathrm{C}\right]$-protein molecular weight markers were run simultaneously. Processed and dried gels were exposed to a phosphorimaging screen 
(Fuji Photo Film Co, Japan) for approximately 3 days, and then scanned on a Bioimaging analyser BAS-1000 MacBas (Fuji Photo Film Co, Japan).

\subsection{PDGF $\beta$ receptor direct kinase assays}

To investigate the inhibitory activities of several compounds against members of the PDGF receptor tyrosine kinase the Alphascreen ${ }^{\mathrm{TM}}$ P-Tyr-100 (phosphotyrosine) assay kit was used. This assay is a bead based luminescent proximity assay in which the binding of molecules captured on donor and acceptor beads leads to an energy transfer. In a 384 well microplate, phosphotyrosine assay buffer (10mM HEPES, 25mM NaCl, $10 \mathrm{mM} \mathrm{MgCl}_{2}, 0.01 \%$ Tween-20, $0.05 \mathrm{mM}$ sodium orthovanadate, $0.3 \%$ DMSO, $10 \mu \mathrm{L}$ ) containing the compound under investigation $(0-100 \mu \mathrm{M})$ was mixed with the kinase $(10 \mu \mathrm{L})$ at a predetermined optimal concentration. The plate was sealed and incubated at room temperature for $20 \mathrm{~min}$ followed by the addition of $1 \mu \mathrm{M}$ Kinase Substrate Biotin (Biotin Glu-Gly-Pro-Trp-Leu-Glu-Glu-Glu-Glu-Glu-Ala-Tyr-Trp-Gly-Trp-Met-Asp-Phe$\mathrm{NH}_{2}$ in $5 \mathrm{mg} / \mathrm{ml}$ BSA in PBS) containing ATP $(80-625 \mu \mathrm{M})$ in phosphotyrosine assay buffer $(10 \mu \mathrm{L})$. The plate was resealed and incubated for $1 \mathrm{~h}$ at $30^{\circ} \mathrm{C}$. Antiphosphotyrosine acceptor beads and streptavidin donor beads were centrifuged (1000 rpm, $1 \mathrm{~min})$ and diluted 1:100 in buffer (10mM HEPES, 25mM NaCl, 0.1M EDTA, $0.01 \%$ Tween-20, 0.1\% BSA, pH 7.2). Donor and acceptor beads (10 $\mu \mathrm{L})$ were added to each well under low lighting conditions, the plate sealed and protected from light for $1 \mathrm{~h}$ at room temperature. The plate seal was removed and after a two minute delay, read on a microplate reader (Fusion ${ }^{\mathrm{TM}_{-}} \alpha$ microplate analyser, Perkin Elmer) at 520-620nm. 


\subsection{Reverse transcription PCR for versican mRNA}

RNA from cultured VSMC cells was extracted with use of TriZol (Invitrogen, Carlsbad, CA, USA) following the manufacturer's protocol and reverse transcription was performed using All-in-one First-strand cDNA synthesis kit (GeneCopoeia, USA). The PCR program (32 cycles) consisted of denaturation for $5 \mathrm{~min}$ at $94^{\circ} \mathrm{C}$, and $94^{\circ} \mathrm{C}$ for 30 seconds, annealing at $55^{\circ} \mathrm{C}$ for 30 seconds, then extension at $72^{\circ} \mathrm{C}$ for $1 \mathrm{~min}$, and extension at $72^{\circ} \mathrm{C}$ for $5 \mathrm{~min}$. NCDN primer sequences were: forward; 5'GCCGCCTTCCAAGGCCAAGA -3'; reverse; 5'- GCCCCTCACCGGTGGGCTTT -3'. The PCR products were examined on $1.2 \%$ agarose gels with ethidium bromide staining.

\subsection{Determination of Egr-1}

Total RNA Preparation and Reverse Transcripatase Reaction - Cells were washed twice with cold PBS and total RNA was extracted with TRIzol® (Life Technologies, Inc.). cDNA was synthesized from $5 \mu \mathrm{g}$ of RNA using the Super Script III First Strand Synthesis Kit (Invitrogen, Carlsbad, USA) as per manufacturer's instructions. cDNA was then stored at $-20^{\circ} \mathrm{C}$.

Real-time PCR - Real-time quantitative PCR was performed using ABI PRISM7700 Sequence Detection System in a final volume of $20 \mu$ l containing $1 \mu 1$ of cDNA, $12.5 \mu 1$ of SYBR Green Master Mix (Applied Biosystems), $0.5 \mu \mathrm{M}$ of forward and reverse primers (Sigma) in DNAse free water at the following PCR conditions: $50^{\circ} \mathrm{C}$ for $20 \mathrm{~min}$, followed by 40 cycles of $95^{\circ} \mathrm{C}$ for 15 seconds and $60^{\circ} \mathrm{C}$ for 1 minute. The target primers for amplifying Human Egr-1 were forward primer: 5'-AGC AGC ACC 
TTC AAC CCT CA-3' and reverse primer: 5'-CAG CAC CTT CTC GTT GTT CAG A3'. Human Glyceraldehyde-3-phosphate dehydrogenase (GAPDH) was used as the internal control with sequence for forward primer: 5'-GAA GGC TGG GGC TCA TTT3' and for reverse primer: 5'-CAG GAG GCA TTG CTG ATG AT-3'. All experiments for real-time RT-PCR were performed in triplicate and data was analysed using the comparative $\mathrm{Ct}$ method. Results are shown as fold induction of mRNA. Primer product size was verified on a $2 \%$ agarose/TBE gel.

\subsection{Western blots}

Total cell lysates were resolved on $10 \%$ SDS-PAGE and transferred onto PVDF. Membranes were blocked with $5 \%$ skim milk powder, incubated with antibodies as described previously [25]. Phospho-PDGF receptor- $\beta$ (Tyr $\left.{ }^{857}\right)$, phospho-PDGF receptor $\beta$ $\left(\mathrm{Tyr}^{1021}\right)$ Egr-1 and $\beta$-actin antibodies were from Santa Cruz Biotechnology Inc. USA, phospho- PDGF receptor- $\beta\left(\mathrm{Tyr}^{751}\right)$ antibodies were purchased from Cell Signaling Technology USA. Anti-human smooth muscle actin antibody was from DakoCytomation Denmark. Secondary antibodies were HRP-anti-species specific IgG and were followed by ECL detection (Amersham).

\subsection{Statistical analyses}

Data was analysed for statistical significance using a 1-way analysis of variance (ANOVA). Results were considered statistically significant at $\mathrm{P}<0.05$ or $\mathrm{P}<0.01$ as stated. Normalisation of data was performed in some investigations to adjust for control variations between individual experiments with data shown as mean \pm SEM. 


\section{$3 \quad$ Results}

It has previously been reported that genistein inhibits PDGF stimulated $\left[{ }^{35} \mathrm{~S}\right]$-sulfate incorporation into proteoglycans secreted by primate VSMCs but it does not block the GAG elongation action of PDGF [18, 24]. To assess if these results pertain to human VSMCs and to extend these findings in relation to the involvement of the PDGF receptor we investigated the effects of genistein and its less active structural analogue, daidzein, along with a well characterised inhibitor, imatinib on PDGF-stimulated proteoglycan synthesis in human VSMCs [13]. Daidzein is the 5-dehydroxy derivative of genistein and lacks tyrosine kinase inhibitory activity [33]. PDGF treatment of VSMCs resulted in an almost one and a half fold increase in $\left[{ }^{35} \mathrm{~S}\right]$-sulfate incorporation into total secreted proteoglycans over $24 \mathrm{~h}$ (Fig. 1, upper panel). Each of the antagonists had a small inhibitory effect on basal rate of incorporation of $\left[{ }^{35} \mathrm{~S}\right]$-sulfate most likely due to some basal level of secretion and activation by growth factors [34]. Radiosulfate incorporation in PDGF treated cells was completely blocked to the basal plus drug level by imatinib $(1 \mu \mathrm{M})$ and genistein $(100 \mu \mathrm{M})$ and it was not blocked by the inactive kinase inhibitor analogue, daidzein $(100 \mu \mathrm{M})($ Fig. 1 upper panel). We then examined the effect of the pharmacological inhibitors on the average apparent size of the biglycan molecules secreted by the human VSMCs (Fig. 1, lower panel). For these molecules the apparent size determined by SDS-PAGE correlates well with size exclusion chromatography [13, 25, 28]. PDGF treatment caused an increase in the average size of biglycan molecules and this response was completely blocked by imatinib and unaffected by genistein and daidzein (Fig. 1, lower panel). These data confirm the original seminal findings of Schonherr and colleagues [18]. 
We then examined the effects of the pharmacological agents on PDGF stimulated proteoglycan core protein expression and secretion. The CPC precipitation method used to assess the culture media after metabolic labelling with $\left[{ }^{35} \mathrm{~S}\right]-\mathrm{met} / \mathrm{cys}$ specifically isolates and allows the quantitation of total proteoglycan core proteins [35, 36]. Although the monkey cells used by Schonherr et al. predominantly secreted versican, the human VSMCs used in this study secrete predominantly biglycan [18, 25]. PDGF stimulated a small increase in $\left[{ }^{35} \mathrm{~S}\right]$-met/cys incorporation into secreted proteoglycans and this was blocked by imatinib and genistein and less so by daidzein (Fig. 2, upper panel). We then examined the effect of PDGF on versican mRNA levels in these cells (Fig 2, lower panel). PDGF treatment lead to an increase in versican mRNA in these human cells as previously reported in monkey VSMCs $[18,37]$. The increase in versican mRNA due to treatment of cells with PDGF was inhibited by genistein (Fig. 2, lower panel). This data is consistent with and confirms the data of Schonherr et al. [18] that genistein blocks PDGF stimulated core protein expression and specifically the expression of versican but it does not block GAG elongation stimulated by PDGF [18].

PDGF signaling occurs through the initial phosphorylation of the autophosphorylation site $\left(\mathrm{Tyr}^{857}\right.$ ) (human PDGF $\beta$ receptor isotype) in the cytosolic split kinase domain of the receptor followed by the internal autophosphorylation of multiple tyrosine residues throughout the cytosolic domain [26, 38]. We analysed the pharmacology of three of these sites associated with the human PDGFR $\beta$ signaling related to the synthesis of proteoglycans [25] - the autophosphorylation site $\mathrm{Tyr}^{857}$, $\mathrm{Tyr}^{751}$ which is associated with Phosphatidyl Inositol-3-Kinase signaling and $\mathrm{Tyr}^{1021}$ associated with Phospholipase- $\gamma$ signaling. Assessing the phosphorylation by Western blotting with 
site specific antibodies showed that the 3 index sites were rapidly and strongly phosphorylated following treatment of cells with PDGF (data not shown). For all three of the target sites the phosphorylation was blocked by imatinib and Ki11502 but it was completely unaffected by genistein at the same concentration $(100 \mu \mathrm{M})$ which completely inhibited PDGF stimulated $\left[{ }^{35} \mathrm{~S}\right]$-sulfate incorporation and core protein expression in the experiments shown in Figs. 1 and 2 (Fig. 3). We investigated whether genistein blocked tyrosine phosphorylation of proteins other than the PDGF receptor using an antiphosphotyrosine antibody on whole cell lysates (Figure 3). The data shows that genistein had a negligible effect on the basal phosphotyrosine proteins of vascular smooth muscle cells. At least ten discrete tyrosine phosphorylated proteins were induced or increased after PDGF treatment. Genistein partially or completely blocked at least four of these PDGF-mediated tyrosine phosphorylated proteins and they were not blocked by imatinib. This clearly shows that genistein can inhibit tyrosine phosphorylation of proteins other than the PDGF receptor.

We then investigated the possibility that there might be signaling independent of the receptor phosphorylation for which there is a small amount of evidence $[39,40]$. For example, it has been demonstrated that the PDGF mediated induction of Egr-1 is independent of the PDGF receptor autophosphorylation on tyrosine [40] so we investigated this possibility in the current model. PDGF stimulated a large increase in the expression of mRNA [3] (Fig. 4, upper panel) and protein (Fig. 4, lower panel) for Egr-1. PDGF stimulation of Egr-1 expression was partially inhibited by the PDGF receptor antagonist, imatinib (Fig. 4, upper and lower panels). The inhibitory response to genistein and daidzein was consistent with their relative activity at tyrosine kinase receptors in that 
genistein was inhibitory and daidzein had no effect (Fig. 4). The data indicates that genistein inhibits a process, most likely a phosphorylation step that leads to Egr-1 expression but this is not occurring at the PDGF receptor.

To further explore the interaction of genistein and the other PDGF receptor antagonists with the PDGF receptor kinase activity, we assessed the effect of multiple agents of interest on PDGF receptor kinase activity in a cell-free in vitro system using the Alphascreen ${ }^{\mathrm{TM}}$ P-Tyr-100 (phosphotyrosine) assay kit. The inhibitory potency of the agents was in the order Ki11502>imatinib>genistein>>daidzein (Fig. 5 and data analysis in Table 1) which is consistent with experimental evidence in several cells systems [13, 21, 41]. Notably, genistein was a full albeit low potency inhibitor of PDGF receptor kinase activity (Fig. 5, upper panel). The calculated parameters relating to the fit of this data to logistical equations is shown in Table 1. This data raises the question as to why genistein did not inhibit the PDGF stimulated phosphorylation of $\mathrm{Tyr}^{857}$ (and other sites) in intact cells as shown in Fig. 3. Kinase inhibitors are mostly of the type that they act by blocking the interaction of the ATP binding site on the kinase with ATP $[16,42]$. For practical reasons of sensitivity in vitro kinase assays are conducted at low ATP concentrations which increases the apparent but not actual potency of the antagonists. It is possible that the absence of inhibitory activity of genistein on PDGF receptor phosphorylation in intact cells arises due to the relatively very high (millimolar) intracellular concentration of ATP $[43,44]$. To evaluate the possibility that genistein is not inhibitory in intact VSMCs because it cannot compete with the high ATP concentration, we undertook the in vitro kinase assays at a wide range of ATP concentrations $(10-200 \mu \mathrm{M})$. There was no effect of the ATP concentration (up to the 
maximum level tested) on the activity of genistein to inhibit PDGF receptor kinase activity (Fig. 5, lower panel). 


\section{Discussion}

In this work we demonstrate that the prototypical receptor tyrosine kinase inhibitor genistein does not block PDGF stimulated phosphorylation of the autophosphorylation site nor of two other phosphorylation sites on the PDGF $\beta$ receptor in human VSMCs. This result provides the explanation for the observation that genistein does not block PDGF stimulated GAG elongation on proteoglycans secreted by these cells because we have reported that this response does involve PDGF receptor phosphorylation [13, 25]. Genistein does block proteoglycan core protein expression but this is due to an action elsewhere than in the PDGF $\beta$ receptor signaling cascade as has been demonstrated for the effect of genistein on VSMC proliferation in which the target is $\mathrm{p} 27^{\mathrm{kip} 1}$ [22].

It has been reported that PDGF stimulates proteoglycan core protein expression and elongation of GAG CS/DS chains on proteoglycans secreted by VSMCs but only core protein expression and not the GAG elongation effect is blocked by the isoflavone tyrosine kinase inhibitor genistein [18]. On the basis that genistein is a protein tyrosine kinase inhibitor, this data lead to the conclusion that the GAG elongation effect did not involve PDGF receptor phosphorylation [18]. We have recently reported that two PDGF receptor antagonists, imatinib and Ki11502, block PDGF receptor $\beta$ phosphorylation and also block PDGF stimulated GAG elongation [13, 25]. On this background we investigated the effects of genistein on PDGF receptor phosphorylation and signaling and proteoglycan synthesis in human VSMCs.

In the current paper we confirm that genistein does not block the GAG elongation effect of PDGF in VSMCs. We demonstrate that genistein does not block phosphorylation of the autophosphorylation site of the PDGF receptor $\beta$ which is the 
predominant receptor type regulating proteoglycan expression in these cells [25] nor does it block the phosphorylation of two other sites on the PDGF receptor. Taken with the data on the inhibitory effect of the PDGF receptor antagonists, imatinib and Ki11502, this strongly suggests that PDGF-stimulated GAG elongation is initiated at and mediated by the PDGF receptor and its phosphorylation and downstream signaling. As we could unequivocally demonstrate that genistein was a highly efficacious albeit low potency inhibitor of PDGF receptor kinase activity in a direct kinase assay (Fig. 5), we further investigated the possible reason for the absence of an inhibitory effect of genistein on PDGF receptor phosphorylation in intact cells. We examined the role of the ATP concentration on the basis that being a competitive inhibitor, a high concentration of ATP might greatly reduce the potency of genistein. We demonstrated that the absence of an inhibitory effect on PDGF receptor phosphorylation was not due to competitive inhibition by the high level of ATP in intact cells.

Genistein blocks PDGF-stimulated versican expression in monkey VSMCs and we demonstrated that it also blocks PDGF-stimulated versican expression in human VSMCs (Fig. 2.). That genistein demonstrates some cellular activity indicates that the drug is getting into the cells albeit that there could be concentration differentials but this is unlikely as the experiments are conducted over the relatively long period of $24 \mathrm{~h}$. Noting the absence of an effect of genistein on PDGF receptor phosphorylation this indicates that this is not the point of action of genistein in blocking proteoglycan core protein expression. In studies of VSMC proliferation genistein inhibits proliferation due to an action targeted at the cell cycle, such as the level of p2 $27^{\text {kip } 1}$ rather than the receptor phosphorylation and immediate downstream signaling [22]. It is likely that the action of 
genistein to block PDGF-stimulated versican expression also resides in cell cycle related pathways. This data indicates that there are distinct signaling pathways for proteoglycan core protein expression and GAG elongation as originally suggested by Schonherr and colleagues [18].

Cell cycle progression is dependent upon a fall in the level of p2 $7^{\mathrm{kip} 1}$ and although genistein inhibits VSMC proliferation by blocking the decrease in $\mathrm{p} 27^{\text {kip } 1}$ levels it remains unclear if the inhibitory action of genistein involves inhibition of protein tyrosine kinase activity at a site other than the PDGF receptor. Cells contain numerous tyrosine kinases which may be targets for genistein although whether or not any of these are upstream of the regulation of $\mathrm{p} 27^{\mathrm{kip} 1}$ remains unknown. Mutation of the critical tyrosine in the autotransphosphorylation and activation site of the PDGF receptor $\beta$, Tyr ${ }^{857}$ in the PDGF receptor $\beta$ to an amino acid (phenylalanine) which cannot be phosphorylated does not reduce the level overall phosphorylation of the receptor in porcine aortic endothelia cells [45]. This suggests that another kinase, as yet unidentified, participates in the phosphorylation of the PDGF receptor upon treatment of cells with PDGF. In this model it is conceivable that genistein, which inhibits PDGF receptor $\beta$ kinase activity in vitro does not inhibit PDGF receptor $\beta$ phosphorylation in intact cells because it does not inhibit the activity of this kinase [45].

\section{Conclusions}

In this work we have demonstrated that genistein in intact VSMCs does not block autophosphorylation and activation of the receptor for PDGF. Taken with the data for imatinib and Ki11502 this demonstrates that PDGF-stimulated GAG elongation is 
initiated at and mediated by the PDGF receptor and its phosphorylation. Insofar as inhibition of VSMC proliferation is concerned the inhibitory action of genistein resides in cell cycle events rather than inhibition of the PDGF receptor signaling pathway. Accordingly, the inhibition of core protein expression (biglycan and versican) may also be occurring elsewhere than the primary PDGF receptor associated signaling pathway. The data extends our understanding of the growth factor and hormone signaling pathways that regulate proteoglycan synthesis in vascular smooth muscle and advances research into the identification and development of a proteoglycan synthesis inhibitor which has the potential to act in concert with a statin drug for the prevention of disease dependent upon lipid deposition in tissues such as atherosclerosis. 


\section{Conflict of interest}

The authors(s) state that they have no conflicts of interest to declare.

\section{Funding}

This work was supported by grants from the National Health \& Medical Research and Project Grant ${ }^{\#} 1022800$ National Heart Foundation of Australia G 09M 4385, and Diabetes Australia Research Trust grants (PJL and NO). LMK was a recipient of an Australia Fellowship from the NHMRC. Mandy Ballinger was supported by Australian Post-graduate Award. This work was also supported by funding from National Natural Science Fund of China (No. 30670652; No. 30711120565; No. 30970935) and Science and Technology Project of Guangdong Province (No. 2011B050200005; No. 2009B060700008) to Wenhua Zheng. 


\section{References}

[1] R. Ross, N Engl J Med 314 (1986) 488-500.

[2] P. Libby, Am J Cardiol 91 (2003) 3A-6A.

[3] P. Fogelstrand, J. Boren, Nutr Metab Cardiovasc Dis 22 (2012) 1-7.

[4] P.J. Little, N. Osman, K.D. O'Brien, Current Opinion in Lipidology 19 (2008) 448-454.

[5] R. Ross, N Engl J Med 340 (1999) 115-126.

[6] Y. Nakashima, H. Fujii, S. Sumiyoshi, T.N. Wight, K. Sueishi, Arterioscler Thromb Vasc Biol 27 (2007) 1159-1165.

[7] Y. Nakashima, T.N. Wight, K. Sueishi, Cardiovasc Res 79 (2008) 14-23.

[8] G. Camejo, A. Lopez, F. Lopez, J. Quinones, Atherosclerosis 55 (1985) 93-105.

[9] P.J. Little, L. Tannock, K.L. Olin, A. Chait, T.N. Wight, Arterioscler Thromb Vasc Biol 22 (2002) 55-60.

[10] L.E. Cardoso, P.J. Little, M.L. Ballinger, C.K. Chan, K.R. Braun, S. PotterPerigo, K.E. Bornfeldt, M.G. Kinsella, T.N. Wight, J Biol Chem 285 (2010) 6987-6995.

[11] M.L. Ballinger, M.E. Ivey, N. Osman, W.G. Thomas, P.J. Little, Atherosclerosis 205 (2009) 451-457.

[12] M.E. Ivey, P.J. Little, Thromb Res 123 (2008) 288-297.

[13] M.L. Ballinger, N. Osman, K. Hashimura, J. de Hann, K. Jandeleit-Dahm, T.J. Allen, L.R. Tannock, J.C. Rutledge, P.J. Little, Journal of Cellular and Molecular Medicine 14 (2010) 1408-1418.

[14] M. Gustafsson, M. Levin, K. Skalen, J. Perman, V. Friden, P. Jirholt, S.O. Olofsson, S. Fazio, M.F. Linton, C.F. Semenkovich, G. Olivecrona, J. Boren, Circ Res 101 (2007) 777-783.

[15] H. Wiegand, A.E. Wagner, C. Boesch-Saadatmandi, H.P. Kruse, S. Kulling, G. Rimbach, Cancer Genomics Proteomics 6 (2009) 85-92.

[16] T. Akiyama, J. Ishida, S. Nakagawa, H. Ogawara, S. Watanabe, N. Itoh, M. Shibuya, Y. Fukami, J Biol Chem 262 (1987) 5592-5595.

[17] A. Levitzki, A. Gazit, Science 267 (1995) 1782-1788.

[18] E. Schonherr, M.G. Kinsella, T.N. Wight, Arch Biochem Biophys 339 (1997) 353-361.

[19] C.Y. Huang, L.Y. Hao, D.E. Buetow, Mol Cell Biochem 233 (2002) 65-72.

[20] E. Schonherr, H.T. Jarvelainen, M.G. Kinsella, L.J. Sandell, T.N. Wight, Arterioscler Thromb 13 (1993) 1026-1036.

[21] P.J. Little, T.J. Allen, K. Hashimura, J. Nigro, C.A. Farrelly, R.J. Dilley, Diabetes Res Clin Pract 59 (2003) 93-101.

[22] J.Y. Yu, J.J. Lee, Y. Lim, T.J. Kim, Y.R. Jin, Y.Y. Sheen, Y.P. Yun, J Pharmacol Sci 107 (2008) 90-98.

[23] P.J. Little, M.L. Burch, R. Getachew, S. Al-aryahi, N. Osman, J Cardiovasc Pharmacol 56 (2010) 360-368.

[24] T.N. Wight, M.J. Merrilees, Circ Res 94 (2004) 1158-1167.

[25] R. Getachew, M.L. Ballinger, M.L. Burch, J.J. Reid, L.M. Khachigian, T.N.

Wight, P.J. Little, N. Osman, Endocrinology 151 (2010) 4356 - 4367.

[26] C.H. Heldin, B. Westermark, Physiol Rev 79 (1999) 1283-1316. 
[27] P.J. Little, N. Osman, S.T. de Dios, N. Cemerlang, M. Ballinger, J. Nigro, Cardiovasc Diabetol 6 (2007) 33.

[28] M.L. Ballinger, J. Nigro, K.V. Frontanilla, A.M. Dart, P.J. Little, Cell Mol Life Sci 61 (2004) 1296-1306.

[29] C.B. Neylon, P.J. Little, E.J. Cragoe, Jr., A. Bobik, Circ Res 67 (1990) 814-825.

[30] L.R. Tannock, E.A. Kirk, V.L. King, R. LeBoeuf, T.N. Wight, A. Chait, J Nutr 136 (2006) 2856-2861.

[31] J. Nigro, R.J. Dilley, P.J. Little, Atherosclerosis 162 (2002) 119-129.

[32] L. Tannock, P.J. Little, T.N. Wight, A. Chait, J Lipid Res 43 (2002) 149-157.

[33] W.C. Ko, C.M. Shih, Y.H. Lai, J.H. Chen, H.L. Huang, Biochem Pharmacol 68 (2004) 2087-2094.

[34] H. Dadlani, M.L. Ballinger, N. Osman, R. Getachew, P.J. Little, J Biol Chem 283 (2008) 7844-7852.

[35] V.C. Hascall, D.K. Heinegard, T.N. Wight, in: E.D. Hay (Ed.), Cell Biology of Extracellular Matrix, Plenum Press, New York, 1991, pp. 149-175.

[36] A.H. Reddi, V.C. Hascall, G.K. Hascall, J Biol Chem 253 (1978) 2429-2436.

[37] E. Schonherr, H.T. Jarvelainen, L.J. Sandell, T.N. Wight, J Biol Chem 266 (1991) 17640-17647.

[38] A. Nakao, E. Roijer, T. Imamura, S. Souchelnytskyi, G. Stenman, C.H. Heldin, P. ten Dijke, J Biol Chem 272 (1997) 2896-2900.

[39] R. Plattner, L. Kadlec, K.A. DeMali, A. Kazlauskas, A.M. Pendergast, Genes Dev 13 (1999) 2400-2411.

[40] L.J. Mundschau, L.W. Forman, H. Weng, D.V. Faller, J Biol Chem 269 (1994) 16137-16142.

[41] R. Getachew, M.L. Ballinger, M.L. Burch, P.J. Little, N. Osman, Eur J Pharmacol 626 (2010) 186-192.

[42] J. Zimmermann, G. Caravatti, H. Mett, T. Meyer, M. Muller, N.B. Lydon, D. Fabbro, Arch Pharm (Weinheim) 329 (1996) 371-376.

[43] P.J. Little, K.D. Drennon, L.R. Tannock, Arch Physiol Biochem 114 (2008) 120126.

[44] P.J. Little, P.L. Weissberg, E.J. Cragoe Jr, A. Bobik, J Biol Chem 263 (1988) 16780-16786.

[45] P. Wardega, C.H. Heldin, J. Lennartsson, Cell Signal 22 (2010) 1363-1368. 
Figure 1. Role of PDGF receptor in PDGF-stimulated proteoglycan synthesis in human VSMCs.

VSMCs were pre-treated for 30 min with Imatinib (Imat), Genistein (Gen) or Daidzein (Daid) and then stimulated with PDGF $(50 \mathrm{ng} / \mathrm{ml})$ for $24 \mathrm{~h}$ in the presence of $\left[{ }^{35} \mathrm{~S}\right]-$ sulfate. (Upper panel). SDS-PAGE analysis of $\left[{ }^{35} \mathrm{~S}\right]$-sulfate incorporated samples (Lower panel). Histogram values are expressed as percentage of untreated control value *P $<0.05$ and $* * \mathrm{P}<0.01$ vs agonist for 3 independent experiments in triplicate.
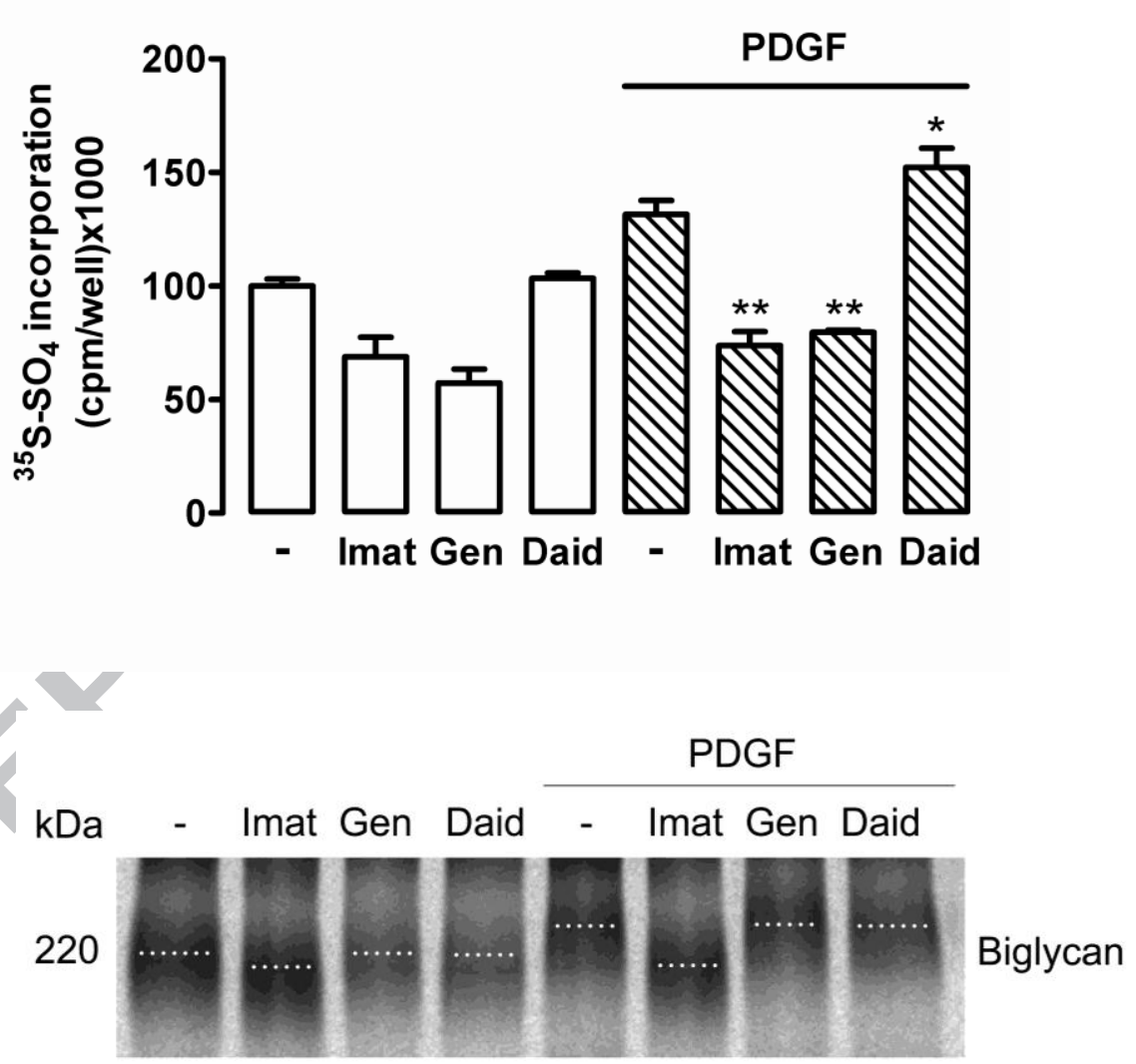
Figure 2. Role of PDGF receptor in PDGF-stimulated proteoglycan core protein synthesis in human VSMCs.

VSMCs were pre-treated for 30 min with Ki11502 (Ki), Imatinib (Imat), Genistein (Gen) or Daidzein (Daid) and then stimulated with PDGF (50 ng/ml) for $24 \mathrm{~h}$ in the presence of $\left[{ }^{35} \mathrm{~S}\right]-\mathrm{Met} / \mathrm{Cys} 24 \mathrm{~h}$. (Upper panel). Human VSMCs were treated with PDGF (50 ng/ml) and the expression of versican (lower panel) determined by RT-PCR as described in Materials and Methods.
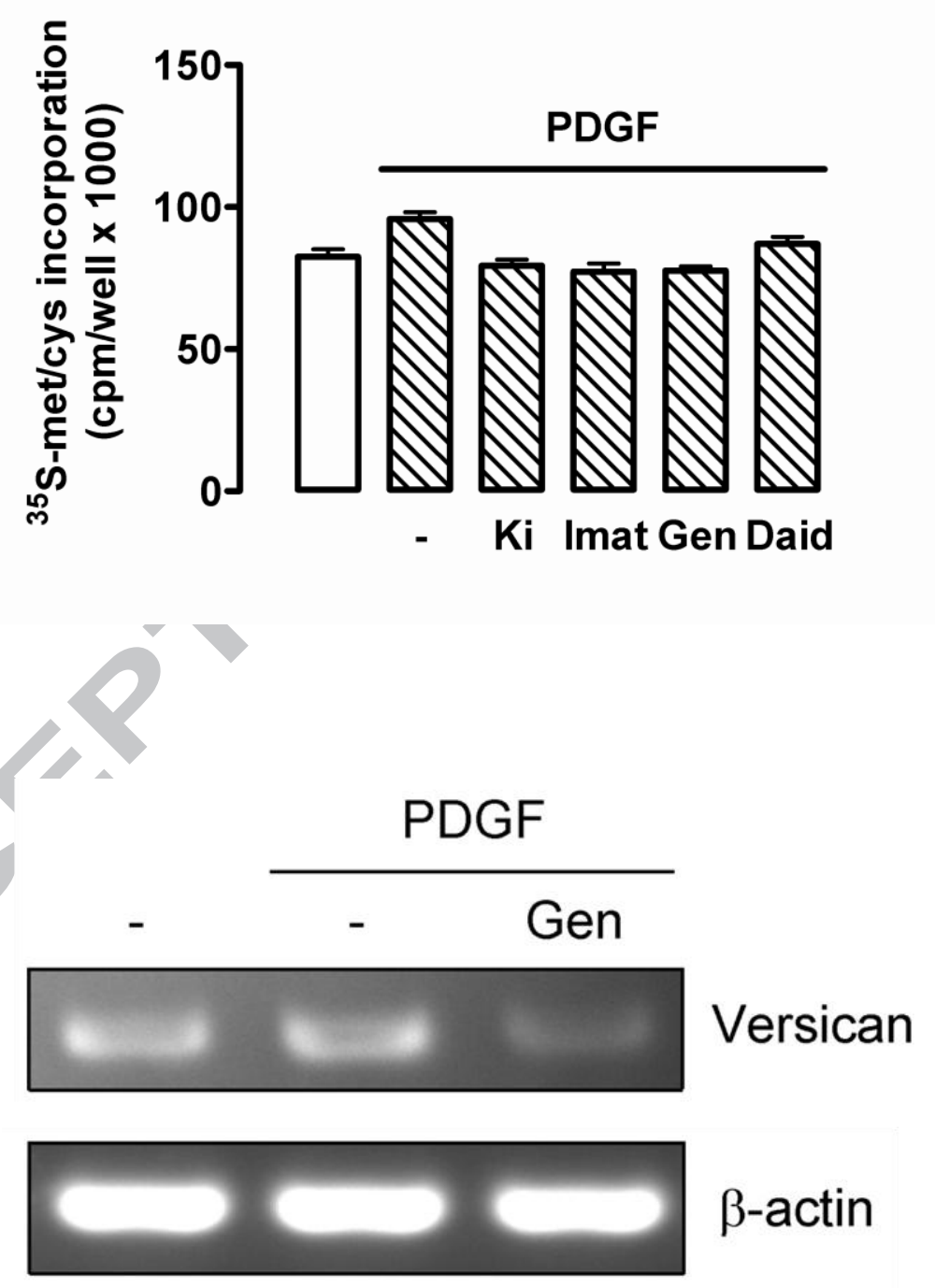
Figure 3. Pharmacology of PDGF induced tyrosine phosphorylation of multiple sites on the PDGF $\beta$ receptor. Western blots of human VSMCs untreated or treated with PDGF-BB (50 ng/ml) for $20 \mathrm{~min}$ in the presence of Ki11502 (Ki), Genistein (Gen) or Imatinib (Imat). PDGFR $\beta$ was probed with anti-phosphoTyr ${ }^{857}$, anti-phosphoTyr ${ }^{751}$, or anti-phosphoTyr ${ }^{1021}$ antibodies as indicated and analysis of whole cell protein tyrosine phosphorylation (right hand panel) probed with anti-phosphotyrosine 4G10 antibody. Arrowheads identify PDGF-induced phosphotyrosine proteins that are affected by genistein pre-treatment. Membranes were reprobed for smooth muscle $\alpha$-actin or GAPDH.

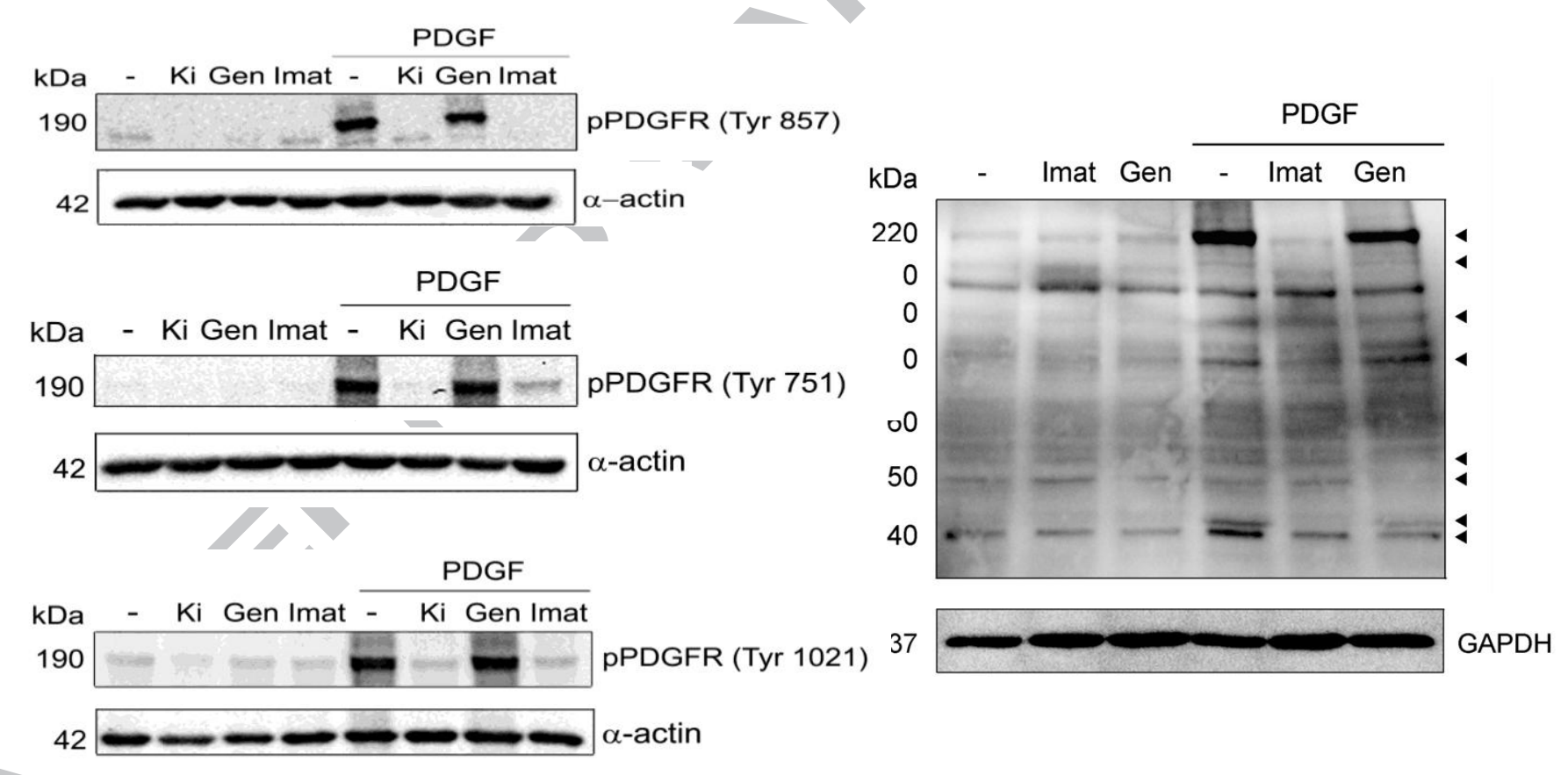


Figure 4. Egr-1 mRNA and protein levels in SMCs pre-treated with inhibitors Genistein (Gen), Imatinib (Imat), Daidzein (Daid) or solvent (Dimethylsulfoxide, DMSO) for $1 \mathrm{~h}$ then exposed to PDGF-BB for 30 min. Egr-1 mRNA experiments were carried out with HSMCs. Egr-1 Western blotting was performed with total extracts from WKY12-22 cells.
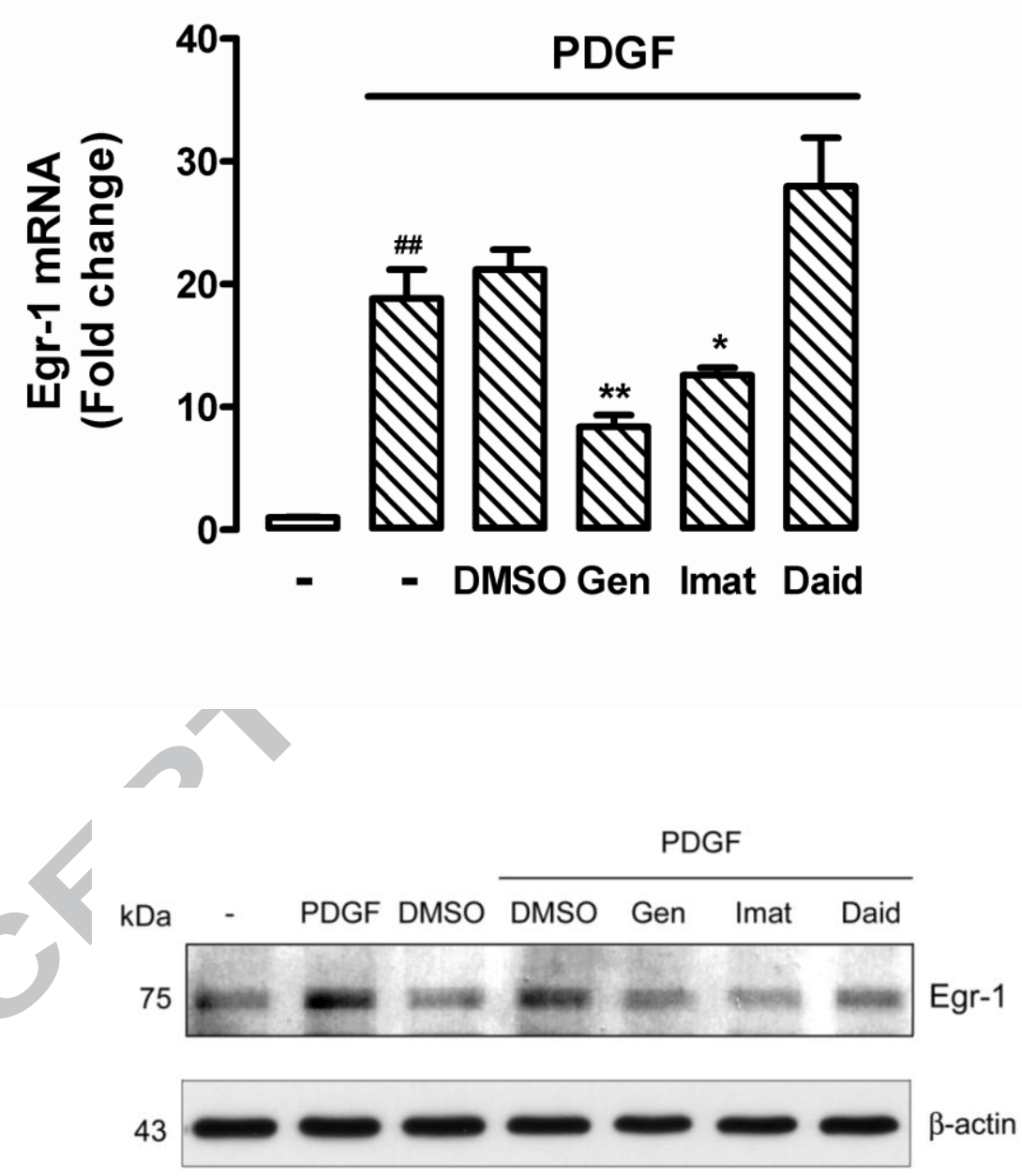
Figure 5. Characterisation of PDGF inhibitors against PDGF receptor kinase activity in a cell free system.

The inhibitory activities of putative PDGF receptor inhibitors against PDGF $\beta$ receptor tyrosine kinase activity using the Alphascreen ${ }^{\mathrm{TM}} \mathrm{P}-\mathrm{Tyr}-100$ (phosphotyrosine) assay kit as describe din Materials and Methods (upper panel). The effect of varying the ATP concentration in the assay on the inhibitory effect of genistein is shown below (lower panel).
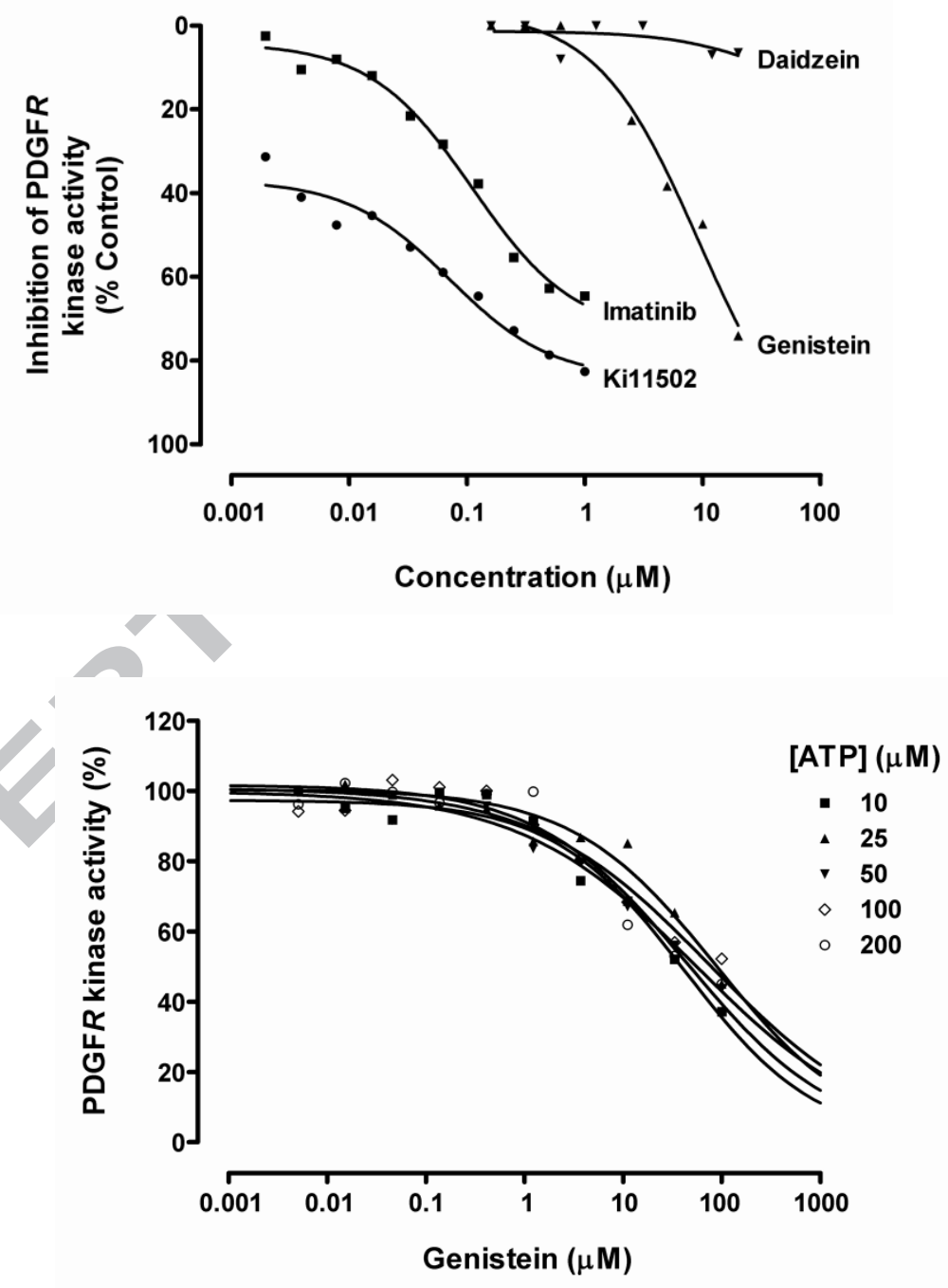
Table 1.Pharmacological parameters for the inhibition of PDGF receptor kinase activity by putative inhibitors. The table shows the mathematical analyses of the data in Fig. upper panel based on a logistical fit of the data generated as described in Materials and Methods

\begin{tabular}{|l|l|l|l|l|}
\hline Parameter & Ki11502 & Imatinib & Genistein & Daidzein \\
\hline $\mathrm{IC}_{50}(\mathrm{nM})$ & 71.2 & 111.6 & 9250 & $>10,000$ \\
\hline Lower fit (\%) & 84.3 & 73.7 & 106.3 & 19.8 \\
\hline Upper fit (\%) & 36.9 & 4.1 & -3.4 & 1.4 \\
\hline $\mathrm{R}^{2}(\%)$ & 96.3 & 98.9 & 98.4 & 34.6 \\
\hline $\mathrm{n}$ & 10 & 10 & 7 & 7 \\
\hline
\end{tabular}




\section{Highlights}

- Genistein does not block PDGF mediated elongation of glycosaminoglycan chains on proteoglycans

- Imatinib and Ki11502 block PDGF stimulated PDGF receptor phosphorylation

- Genistein does not block PDGF stimulated phosphorylation of the PDGF receptor

- Genistein blocks PDGF receptor kinase activity in vitro

- Absence of inhibitory action of genistein is not due to high ATP concentration 